\title{
The Effects of DNA Synthesis Inhibitors on Cell Cycle Synchronization in Cucumber (Cucumis sativus L.) Root Meristems
}

\author{
Yoshikazu Hoshi ${ }^{1, *}$, Takayuki Nakayama ${ }^{1}$, Wojciech Pląder ${ }^{2}$, Stefan Malepszy ${ }^{2}$ \\ and Jaroslav Doleže $\left.\right|^{3}$ \\ ${ }^{1}$ Department of Chemical and Biological Engineering, Ariake National College of \\ Technology, 150 Higashi-Hagio, Omuta, Fukuoka 836-8585, Japan \\ ${ }^{2}$ Department of Plant Genetics and Biotechnology, Warsaw Agricultural University, ul. \\ Nowoursnowska 166, PL-02787 Warszawa, Poland \\ ${ }^{3}$ Institute of Experimental Botany, Academy of Sciences of the Czech Republic, \\ CZ-772 00 Olomouc, Czech Republic
}

Received May 7, 2004; accepted May 27, 2004

\begin{abstract}
Summary The effects of hydroxyurea (HU) and aphidicolin (APD) on cell cycle synchronization in cucumber root meristems were studied. A 10 times lower HU concentration was effective for cucumber synchronization compared to that used as a typical treatment in Vicia faba or Triticum aestivum, and the peak mitotic index (MI) was $5 \mathrm{~h}$ after inhibitor removal. Higher APD concentrations (15 $\mu \mathrm{M}$ and above) caused the accumulation of $\mathrm{M}$ phase cells, and the peak MI was $4 \mathrm{~h}$ after its removal. After release from the HU block, the use of Hoagland's nutrient solution on cell cycle synchronization resulted in a considerable increase in MI. The efficiency of colchicine was also very high, and cells at anaphase or telophase were observed at very low frequencies. The highest MI (39\%) was obtained $4 \mathrm{~h}$ after an $18 \mathrm{~h}$ APD block at $15 \mu \mathrm{M}$ followed by $0.05 \%$ colchicine treatment for $2 \mathrm{~h}$. Our synchronizing procedure in C. sativus would be very helpful for flow-sorting of mitotic chromosomes, karyomorphological analysis, and genetic analysis.
\end{abstract}

Key words DNA synthesis inhibitors, Cell cycle synchronization, HU, APD.

DNA synthesis inhibitors are essential for plant cell synchronization, which is a critical requirement for flow-sorting of mitotic chromosomes, karyomorphological analysis, and genetic analysis. To achieve flow-sorting using a high-quantity suspension of cells synchronized at metaphase, establishment of a cell-cycle synchronization method is highly desired. Protocols for cell cycle synchronization in higher plants such as common wheat and pea have been reported previously (Doležel et al. 1992, Neumann et al. 1998, Vrána et al. 2000). To synchronize the cells in these plants, DNA synthesis inhibitors have been used. In addition, root meristems have been chosen from plant tissues for cell cycle synchronization because root tips are highly enriched in rapidly cycling cells. (Doležel et al. 1999).

Cucumis sativus chromosomes have been completely identified and show different band intensities by C-banding or fluorescent in situ hybridization (FISH) (Hoshi et al. 1998, Plader et al. 1998), which means that $C$. sativus chromosomes can be isolated by cell sorting. Sorted chromosome fractions can be used for constructing chromosome-specific gene libraries (Doležel et al. 1992). Thus, improvements for methods of cell cycle synchronization are important and a matter of the highest priority in work with C. sativus. In this study, we surveyed the effect of DNA synthesis inhibitors on dividing cells of cucumber. We investigated the effects of two types of DNA synthesis inhibitors on cell cycle synchronization, and estimated the time at which mitotic activity peaked in

\footnotetext{
*Corresponding author, e-mail: hoshi@ariake-nct.ac.jp
} 
order to obtain a high number of metaphase cells.

\section{Materials and methods}

Seeds of Cucumis sativas L. var Monastyrski $(2 n=2 x=14)$ were used in this study. The protocol used for cell cycle synchronization has been described previously (Doležel et al. 1992, 1999, Kaeppler et al. 1997). All incubations were performed in the dark at $28^{\circ} \mathrm{C}$ except for colchicine treatment. For distilled water cultures, seeds were germinated on filter paper moistened with distilled water in a glass petris dish for $54 \mathrm{~h}$ to achieve optimal root length $(2-3 \mathrm{~cm})$. Seedlings were transferred to filter papers moistened with solutions of various concentrations of hydroxyurea (HU) $(0.125 \mu \mathrm{M}-1250 \mu \mathrm{M})$ or aphidicolin (APD) $(0.015 \mu \mathrm{M}-150 \mu \mathrm{M})$ in glass petri dishes to block DNA synthesis and incubated for $18 \mathrm{~h}$. The roots were then washed in distilled water and transferred to filter papers moistened with distilled water in a glass petri dish to recover from HU or APD blocks. Samples of root tips were taken at $1 \mathrm{~h}$ intervals up to $10 \mathrm{~h}$ for analysis of cell cycle synchrony and mitotic activity. For seedling cultures treated with Hoagland's nutrient solution, seeds were germinated on filter papers moistened with distilled water for $24 \mathrm{~h}$ and incubated on filter papers moistened with Hoagland's nutrient solution for $30 \mathrm{~h}$. In addition, the HU and APD treatments and recovery treatments were prepared using Hoagland's solution instead of distilled water. To accumulate cells at metaphase, seedlings were cut into $1.5 \mathrm{~cm}$ pieces after recovery from $\mathrm{HU}$ or APD blocks and transferred to $1.5 \mathrm{ml}$ microtubes for $0.05 \%$ colchicine treatment at $18^{\circ} \mathrm{C}$ for $2 \mathrm{~h}$. To determine mitotic activity and to observe chromosomes, root tips were fixed in $45 \%$ acetic acid on ice for $30 \mathrm{~min}$, hydrolyzed with hydrochloric acid:acetic acid $(2: 1)$ at $60^{\circ} \mathrm{C}$ for $15 \mathrm{sec}$, stained with $1 \%$ aceto-orcein for $6 \mathrm{~h}$ or $10 \mu \mathrm{g} / \mathrm{ml} \mathrm{4}$, 6 -diamidino-2-phenylindole (DAPI) for $30 \mathrm{~min}$, and then prepared according to the squash method (Hoshi et al. 1998). For orcein staining, 300 cells per slide and 10 preparations per variant were observed using a microscope (CH30, Olympus) and the mitotic index (MI) was determined. Chromosomes stained with DAPI were observed using a fluorescence microscope (BX60, Olympus).

\section{Results and discussion}

\section{Effects of DNA synthesis inhibitors}

The results of cell cycle synchronization in root tip meristems are shown in Fig. 1. The MI showed that lower concentrations (less than $0.15 \mu \mathrm{M}$ ) of HU and APD had the same effect as control treatments (16.7\%). Higher APD concentrations (15 $\mu \mathrm{M}$ and above) caused accumulation of $\mathrm{M}$ phase cells ( $\geq 19.6 \%$ ), while higher HU concentrations ( $15 \mu \mathrm{M}$ and above) did not $(\geq 14.8 \%)$. In addition, treatment with $1250 \mu \mathrm{M}$ HU, which was the optimum concentration for pea (Doležel et al. 1999), gave few M phase cells. Synchronized cells of root tip meristems obtained after HU treatment are shown in Fig. 2. The results indicate that HU had the ability to accumulate M phase cells. HU is one of the most effective reagents in cell cycle studies, as it can be used to synchronize cells at the G1/S interface (Hung et al. 1996). However, Doležel et al. (1999) observed that, unlike HU, APD was not toxic to cells in S phase. Although the degree of synchrony in root tips induced by HU and APD are comparable, APD has been

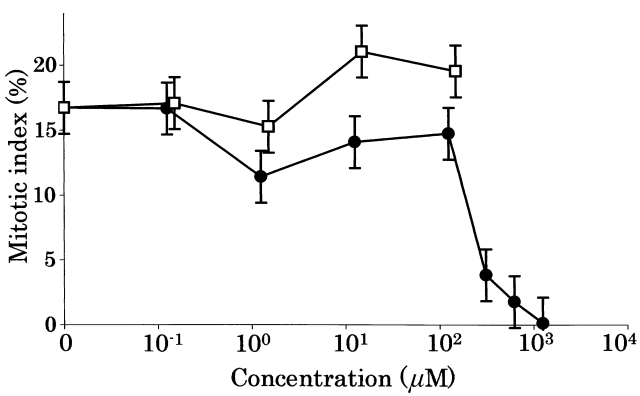

Fig. 1. Mitotic index observed in root tip meristems after recovery for $10 \mathrm{~h}$ from varied concentrations of APD $(\square)$ or HU ( ) blocking. Error bars indicate the standard deviation. 

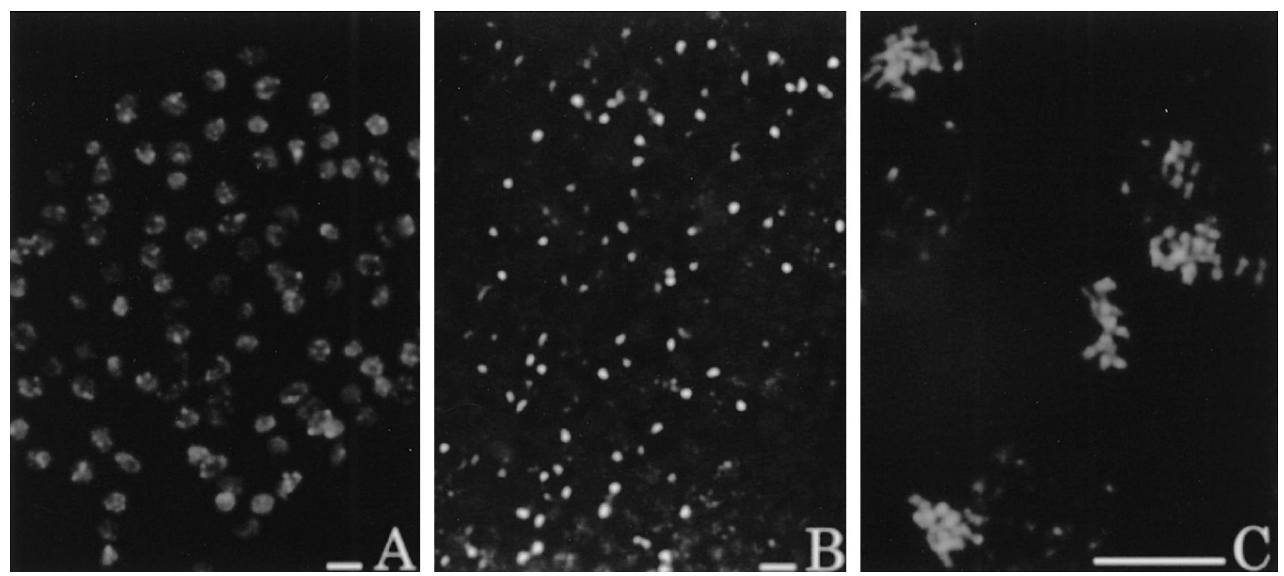

Fig. 2. Cells in cucumber root tip meristems accumulating after no treatment (A) or with HU treatment (B and C). Many chromosomes were observed after cell synchronization (C). Bar $=20 \mu \mathrm{m}$.
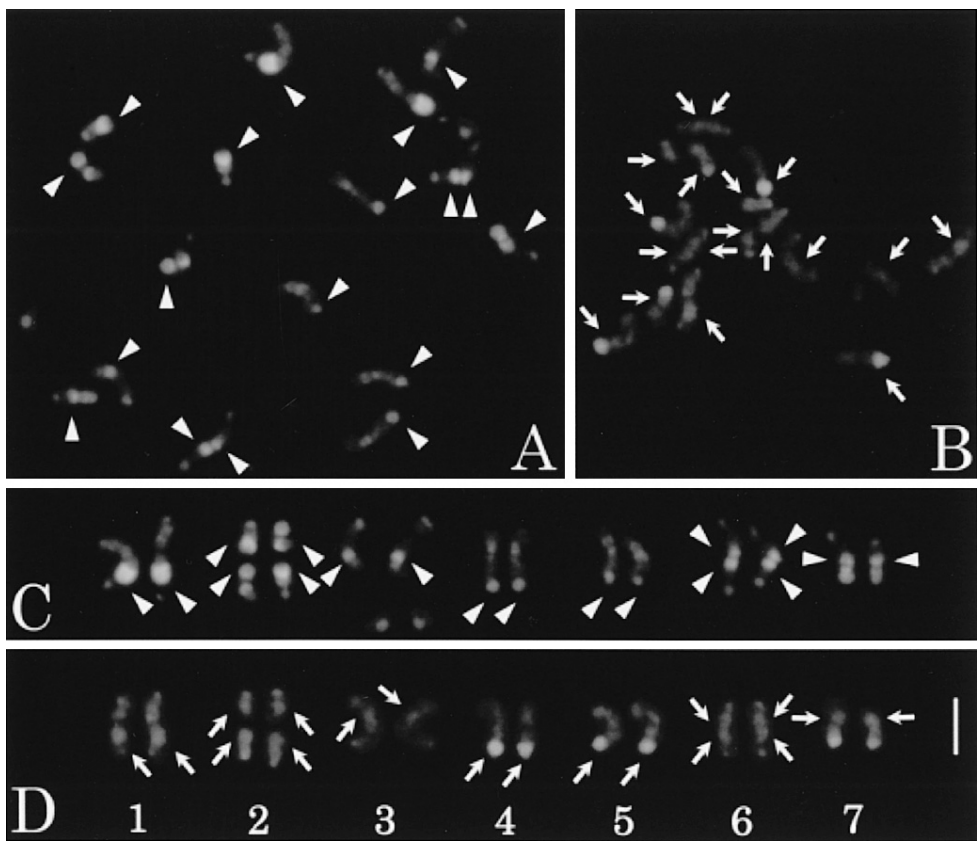

Fig. 3. Chromosomes of C. sativus after DAPI staining. Metaphase chromosomes (A and B) without treatment (A and C) and with HU treatment (B and D) were aligned (C and D). Several DAPI positive bands (arrowheads) showed changes in band intensities (arrows) after HU treatment. Bar $=5 \mu \mathrm{m}$.

used less frequently (Doležel et al. 1999). Studies of cell cycle synchronization using HU have been previously reported in other higher plants such as Vicia faba and Triticum aestivum; the optimal HU concentration for cell cycle synchronization was 1250-2500 $\mu \mathrm{M}$ in Vicia faba and Triticum aestivum (Doležel et al. 1999, Vrána et al. 2000). Therefore, a 10 times lower HU concentration was effective for cucumber synchronization compared to typical blocking treatments in Vicia faba or Triticum aestivum. HU induces chromosome damage in a number of organisms including humans (Timson 1975). Our karyotype analysis of cucumber cells also showed similar events (Fig. 3). Several DAPI positive bands showed changes in band intensities after HU treatment (Fig. 3, arrows and arrowheads). Doležel et al. (1999) showed that the concentration of DNA synthesis inhibitor that 
had a given level of cell cycle control or cytotoxicity depends on plant species. Our results suggest that high concentrations of HU might give poor cell cycle synchronization due to cytotoxic and mutagenic effects, as observed by changes in heterochromatin bands. Thus, investigation of the effective concentration of a DNA synthesis inhibitor is very important. Our survey will be useful to optimize HU and APD concentrations as a first step to establishing cell cycle synchronization and heterochromatin structure analysis in C. sativus.

\section{Analysis of cell cycle synchrony}

The MI after the removal of DNA synthesis inhibitor is shown in Fig. 4. The results indicate that a peak MI was obtained 4 to $5 \mathrm{~h}$

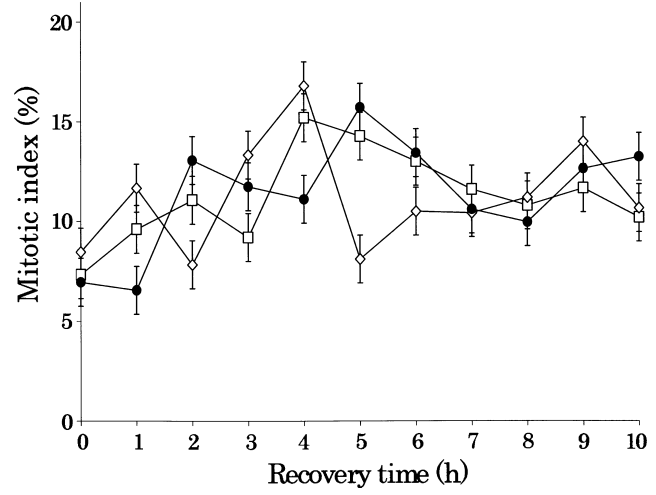

Fig. 4. Mitotic index during the recovery from a DNA inhibitor block in root tip meristems. Mitotic index was determined at $1 \mathrm{~h}$ intervals after inhibitor removal. APD was used at $15 \mu \mathrm{M}(\square)$ or $75 \mu \mathrm{M}(\diamond)$. HU was used at $125 \mu \mathrm{M}(\bullet)$. Error bars indicate the standard deviation. Values are the average of 3 experiments. after removing from $\mathrm{HU}$ and APD blocks in cucumber seedlings. In other plants, 6 to $10 \mathrm{~h}$ recovery treatments showed maximum MI values (Doležel et al. 1999, Neumann et al. 1998, Vrána et al. 2000). The recovery time for cucumber cell cycle synchronization was shorter than that reported previously for other plants. Bennett (1998) described that the duration of the minimum mitotic cell cycle in some diploid species was related closely to genome size. Chromosomes of $C$. sativus are relatively small, varying in length from 1.2 to $2.5 \mu \mathrm{m}$ at mitotic metaphase (Hoshi et al. 1998, Koo et al. 2002, Chen et al. 2003). The shorter recovery time for effective metaphase accumulation might be due to the short cell cycle and small genome size or to late DNA replication.

\section{Application of Hoagland's nutrient solution}

The effect of Hoagland's nutrient solution on cell cycle synchronization is shown in Fig. 5. The use of Hoagland's nutrient solution resulted in a considerable increase in MI after release from the HU block. On the other hand, the MI was nearly the same as the control treatment after release from the APD block. HU was toxic to cells in S phase (Doležel et al. 1999), and we have already suggested that HU might give poor cell cycle synchronization due to cytotoxicity. Thus, these results suggest that Hoagland's nutrient solution gives the possibility of decreasing the cytotoxicity of HU treatment, and nearly the same effects as APD treatment because APD is not toxic to cells in S phase (Doležel et al. 1999). Hoagland's nutrient solution has been used for cell cycle synchronization in other plants (Doležel et al. 1992, 1999, Kaeppler et al. 1997). Our survey showed that Hoagland's nutrient solution was as effective in C. sativus as in other plants.

\section{Application of colchicine}

The data describing the relationship of cell frequency with MI after colchicine treatment are shown in Fig. 6. The efficiency of colchicine was very high, and cells at anaphase or telophase were observed at very low frequencies. The colchicine treatment increased the $\mathrm{M}$ phase frequency $(\geq 20 \%)$. The highest MI (40\%) was obtained $4 \mathrm{~h}$ after the $18 \mathrm{~h}$ APD block at $15 \mu \mathrm{M}$ followed by $0.05 \%$ colchicine treatment for $2 \mathrm{~h}$. Colchicine accumulates cells in metaphase to the same extent as amiprophos-methyl (APM), and it is widely used. Doležel et al. (1999) observed that although colchicine has been widely used, its affinity for plant tubulins is low and thus it must be applied at relatively high concentrations. Additionally, they noted that APM is not commercially available. Our results showed that colchicine has enough effectiveness to accumulate $C$. sativus cells in 


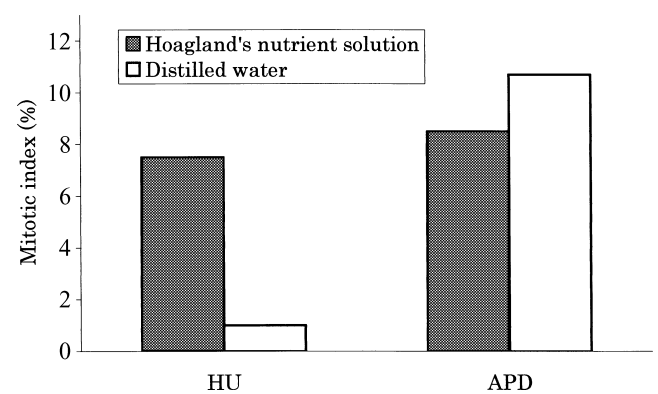

Fig. 5. Mitotic index observed in root tip meristems of cucumber treated with Hoagland's nutrient solution. Optimal concentrations of $\mathrm{HU}(1250 \mu \mathrm{M})$ and $\mathrm{APD}(1.5 \mu \mathrm{M})$ in other plants were used.

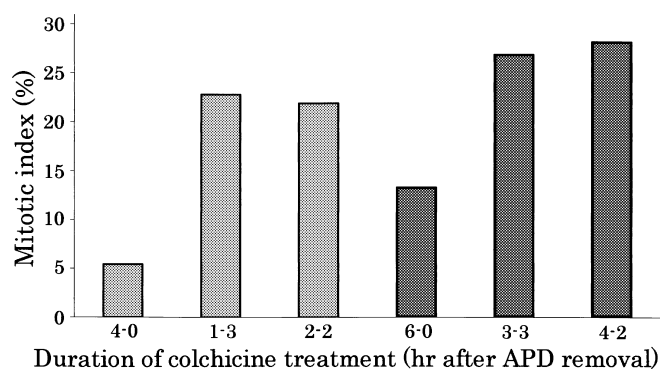

Fig. 6. Mitotic index and frequency of various phases of mitosis observed in root tip meristems of cucumber $x \mathrm{~h}$ after the $18 \mathrm{~h}$ APD block at $15 \mu \mathrm{M}$ followed by $0.05 \%$ colchicine treatment for $y \mathrm{~h}$, where the annotation $(x, y)$ indicates, respectively, treatment delay and duration. Values are the average of 3 experiments.

metaphase. In this study, we established cell cycle synchronization in C. sativus. Further study is required to develop stable and more efficient protocols for cell cycle synchronization.

\section{References}

Bennett, M. D. 1998. Plant genome values: How much do we know? Proc. Natl. Acad. Sci. U.S.A. 95: 2011-2016.

Chen, J., Staub, J., Qian, Ch., Jiang, J., Luo, X. and Zhuang, F. 2003. Reproduction and cytogenetic characterization of interspecific hybrids derived from Cucumis hystrix Chakr.×Cucumis sativus L. Theor. Appl. Genet. 106: 688-695.

Doležel, J., Č́halíková, J. and Lucretti, S. 1992. A high-yield procedure for isolation of metaphase chromosomes from root tips of Vicia faba L. Planta 188: 93-98.

—, - Weiservá, J. and Lucretti, S. 1999. Cell cycle synchronization in plant root meristems. Methods Cell Sci. 21: 95-107.

Hoshi, Y., Pla,der, W. and Malepszy, S. 1998. New C-banding pattern for chromosome identification in cucumber (Cucumis sativus L.). Plant Breed. 117: 77-82.

Hung, D. T., Jamison, T. F. and Schreiber, S. 1996. Understanding and controlling the cell cycle with natural products. Chem. Biol. 3: 623-639.

Kaeppler, H. F., Kaeppler, S. M., Lee, J. H. and Arumuganathan, K. 1997. Synchronization of cell division in root tips of seven major cereal species for high yields of metaphase chromosomes for flow-cytometric analysis and sorting. Plant Mol. Biol. Rep. 15: 141-147.

Koo, D. H., Hur, Y., Jin, D. C. and Bang, J. W. 2002. Karyotype analysis of a Korean cucumber cultivar (Cucumis sativus L. cv. Winter Long) using C-banding and bicolor fluorescence in situ hybridization. Mol. Cells 13: 413-418.

Neumann, P., Lysák, M., Doležel, J. and Macas, J. 1998. Isolation of chromosomes from Pisum sativum L. hairy root cultures and their analysis by flow cytometry. Plant Sci. 137: 205-215.

Pla,der, W., Hoshi, Y. and Malepszy, S. 1998. Sequential fluorescent staining with CMA and DAPI for somatic chromosome identification in cucumber (Cucumis sativus L.). J. Appl. Genet. 39: 249-258.

Timson, J. 1975. Hydroxyurea. Mutat. Res. 32: 115-132.

Vrána, J., Kubaláková, M., Šimková, H., Č́halíková, J., Lysák, M. A. and Doležel, J. 2000. Flow sorting of mitotic chromosomes in common wheat (Triticum aestivum L.). Genetics 156: 2033-2041. 